\title{
Hospitality in Antiquity:
}

\section{Livy's Concept of Its Humanizing Force}

\section{by Ladislaus J. Bolchazy}

A corrected reprint of the 1977 edition, Hospitality in Early Rome

"Bolchazy shows clearly the importance that Livy attaches to hospitality throughout his History ... he has done a real service by drawing attention to the civilizing force which Livy believed hospitality to exercise."

-R. M. Ogilvie

"Especially praiseworthy, in my view, is Bolchazy's method, which uses the theories and findings of cultural anthropology as the basis for analyzing the practical and ethical functions of hospitality in early Greece and Rome. Bolchazy rightly emphasizes the primary role played by the problem of the "reception of strangers" in forming higher-level cultural attitudes. The once shunned practice of mining the rich ethnographic record of "primitive" and "archaic" societies for insights into the social and psychological structures of classical antiquity has gained steady acceptance in recent years. Bolchazy's sure-handed use of the comparative evidence in 1977 marks him as a pioneer of the methodology."

-Walter Donlan

"The main point of the thesis is very important since it shows that the concept of human rights and the brotherhood of man does not necessarily depend upon religious beliefs but has autonomous ethical roots."

Sidney Hook

"A significant work of scholarship ... that will have a wide range of interested readers."

-Gordon M. Kirkwood

"A model in literary exegesis. Also commendable is Bolchazy's knowledge and application of anthropological data."

-Blaise Nagy

"This is all new and very interesting."

-Theodore J. Tracy

"A scholarly and well-documented work." -Thomas S. Corcoran

New Paperback, ISBN 0-89005-212-3: $\$ 20.00$

Order from:

ARES PUBLISHERS, Inc.

7406 Sheridan Rd., Chicago, IL 60026

(312) 743-1405; Fax: (312) 743-0657 